\title{
Vegetable Microbiology: Concern for Human Health
}

\author{
Bhallan Singh Sekhon*, Yudhvir Singh, Surbhi Sharma, Simran Sharma and Vishalakshi \\ Department of Vegetable Science \& Floriculture, Chaudhary Sarwan Kumar Himachal Pradesh, Krishi Vishvavidyalaya, Palampur, India
}

*Corresponding author: Bhallan Singh Sekhon, Department of Vegetable Science \& Floriculture, Chaudhary Sarwan Kumar Himachal Pradesh, Krishi Vishvavidyalaya, Palampur-(H.P.)-176062, Himachal Pradesh, India

Submission: 眥January 26, 2018; Published: 紫 February 08, 2018

Opinion

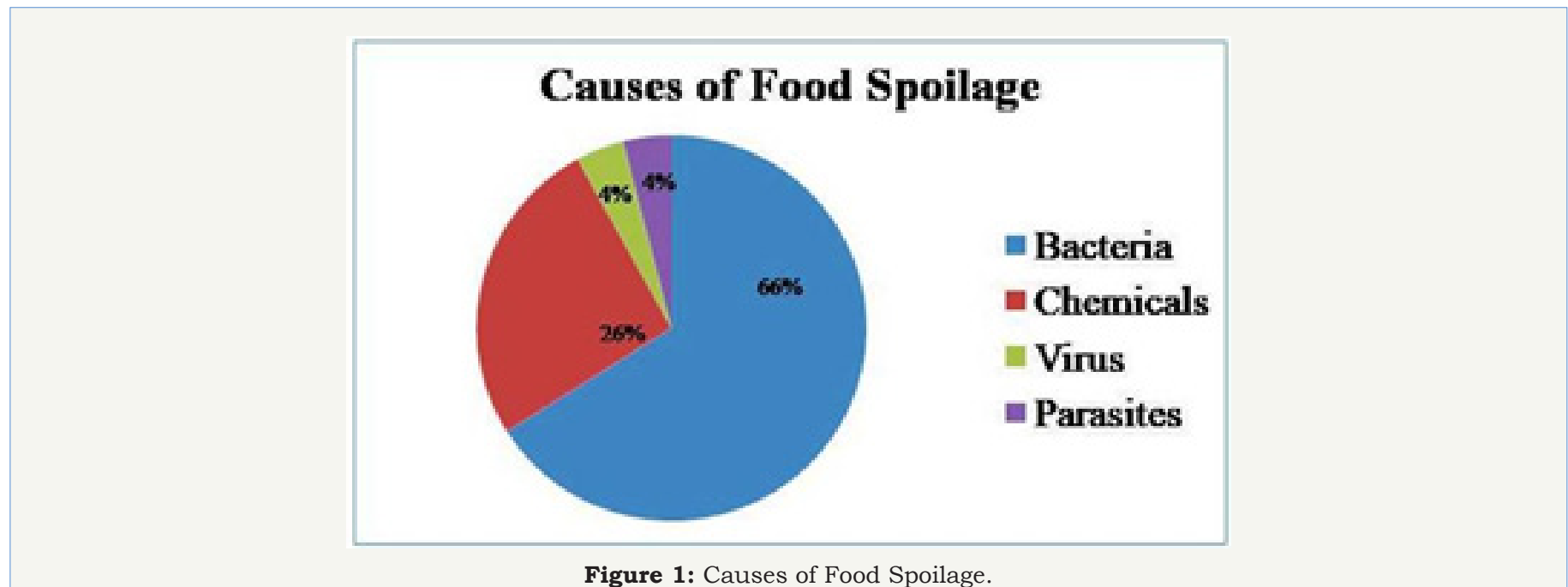

In the health conscious society of 21st century, vegetables form an integral part of human diet. They provide us essential vitamins and minerals, dietary fiber, phytochemicals, and also help in reducing the risk of dangerous diseases [1]. World Health Organization (WHO), European Food Safety Authority (EFSA), Food \& Agricultural Organization (FAO) and French Agency for Food Safety (AFSSA) recommended the intake of atleast five servings of vegetables and fruits per day [2]. In general, freshly consumed vegetables are considered to be more vital than the cooked ones. However, they are usually accompanied with many food borne diseases, thus poses safety threats [3]. Ready to Eat (RTE) vegetables, generally grown near the metropolitan cities are cultivated in unhygienic environments [4], irrigated with poor quality water [5], and fertilized using organic and inorganic amendments [6,7]. This all leads to microbial contamination and spread of infectious diseases like diarrhoea, Salmonellosis and Shigellosis etc. in humans. Bacteria are reported to be the major villain (Figure 1) among the causes of food borne illness [8]. Bacteria associated or isolated from different raw vegetables have been documented in article entitled "Recent Trends in Microbiological Safety of fruits and vegetables" by [9].

Extended list of microbial outbreaks that occurred through contaminated vegetables has been provided by [10] in their excellent review on "Microbial contamination and behavior of enteropathogens in phyllosphere". Further, there are reports of microbial contamination of fresh vegetables above recommended thresholds in comparison to International standards, in different parts of the world [3-11]. Country wise list of RTE vegetables containing bacterial pathogens along with remedial measures have been listed by [12]. Comprehensive information on "Vegetable Microbiology" right from the sources of contamination to its consequences on human health is available in above mentioned literature [3-12].

After thorough study of available literature, author realized the importance of dissemination of knowledge pertaining to the subject, he named "Vegetable Microbiology". First of all, initiation of awareness programmes is the need of hour. The chain of programme must begin from farmers then to the sales person and finally towards the consumers. Special attention needs to be directed toward the source of contamination and its treatment $[13,14]$. This could be possible at farm level. Then next treatment i.e. thorough washing of vegetables with running water or with sanitizers or any other type of innovative treatments might be done at market level. Finally, awareness among consumers is also a major concern, particularly, among those who consume vegetables from their home gardens. Unknowingly, they are consuming microbial 
strains along with fresh produce which results in the spread of infectious diseases. To minimize such risks of contamination, Good

(GMP) must be followed at all points from the field to the fork [12] Agricultural Practices (GAP) and Good Manufacturing Practices

(Table 1).

Table 1: Vegetables reported with microbial contamination and their possible prevention.

\begin{tabular}{|c|c|c|c|}
\hline Crop & $\begin{array}{c}\text { Microbial } \\
\text { Contamination }\end{array}$ & Methods for Prevention & Reference \\
\hline \multirow{3}{*}{ Lettuce } & Faecal coliform & Vinegar based washing & Woldetsadik et al. [5] \\
\hline & $\begin{array}{l}\text { Helminth parasitic } \\
\text { infections. }\end{array}$ & Physical washing with running water & Woldetsadik et al. [5] \\
\hline & Escherichia coli $0157: \mathrm{H7}$ & & Buck et al. [9] \\
\hline \multirow{3}{*}{ Ready to Eat (RTE) Vegetable Salads } & Escherichia coli & \multirow{3}{*}{$\begin{array}{l}\text { Identifying and eliminating possible } \\
\text { sources of contamination. } \\
\text { Modified Atmospheric storage and } \\
\text { refrigeration to enhance shelf-life }\end{array}$} & \multirow{3}{*}{$\begin{array}{c}\text { Mir et al. [3] } \\
\text { Campos et al. [13] } \\
\text { Pothakos et al. [14] }\end{array}$} \\
\hline & Listeria monocytogenes & & \\
\hline & Salmonella & & \\
\hline Carrot & Enterotoxigenic E. coli & \multirow{10}{*}{$\begin{array}{l}\text { General Recommendations discussed } \\
\text { 1. Washing and Rinsing } \\
\text { 2. Use of disinfectants and sanitizers } \\
\text { 3. Chemical seed treatments for sprout } \\
\text { seed including chlorine compounds } \\
\text { (e.g., calcium and sodium hypochlorite), } \\
\text { ethanol, etc. } \\
\text { 4.Thermotherapy (Exposing seeds to } \\
\text { temperatures of } 57 \text { to } 60^{\circ} \mathrm{C} \text { for short } \\
\text { periods (e.g., } 10 \text { min)). } \\
\text { 5. Use of Ionizing radiation } \\
\text { 6. Seed Testing }\end{array}$} & \multirow{10}{*}{ Buck et al. [9] } \\
\hline \multirow{2}{*}{ Cauliflower } & Aeromonas & & \\
\hline & Salmonella & & \\
\hline \multirow[t]{2}{*}{ Cabbage } & Clostridium botulinum & & \\
\hline & Salmonella & & \\
\hline \multirow{2}{*}{ Tomato } & Listeria monocytogenes & & \\
\hline & Salmonella & & \\
\hline \multirow{2}{*}{ Cucumber } & Bacillus cereus & & \\
\hline & Listeria monocytogenes & & \\
\hline Spinach & Salmonella & & \\
\hline
\end{tabular}

\section{Acknowledgement}

First author greatly acknowledge DST-INSPIRE fellowship for providing financial support during his Ph.D. programme and inspiring him to think "out of the box" and write article on "Microbiological aspect of Vegetables".

\section{References}

1. Sharma A, Sekhon BS (2016) Technical Section: Importance and future prospects of vegetables. Himjyoti, India, p. 53.

2. Toe E, Dadie AT, Dako E, Lookou G (2017) Bacteriological quality and risk factors for contamination of raw mixed vegetable salads served in collective catering in abidjan (Ivory Coast). Advances in Microbiology $7(1):$ 405-419.

3. Mir SA, Shah MA, Mir MM, Dar BN, Greiner R, et al. (2017) Microbiological contamination of ready-to-eat vegetable salads in developing countries and potential solutions in the supply chain to control microbial pathogens. Food Control 85: 235-244.

4. Nawas T, Mazumdar RM, Das S, Nipa MN, Islam S, et al. (2012) Microbiological quality and antibiogram of E. coli, Salmonella and Vibrio of salad and water from restaurants of Chittagong. J Environ Sci \& Natural Resources 5(1): 159-166.

5. Woldetsadik D, Drechsel P, Keraita B, Itanna F, Erko B, et al. (2017) Microbiological quality of lettuce (Lactuca sativa) irrigated with wastewater in Addis Ababa, Ethiopia and effect of green salads washing methods. International Journal of Food Contamination 4:3.

6. Alam MS, Feroz F, Rahman H, Das KK, Noor R (2015) Microbiological contamination sources of freshly cultivated vegetables. Nutrition \& Food Science 45(4): 646-658.

7. Faour-Klingbeil D, Murtada M, Kuri V, Todd EC (2016) Understanding the routes of contamination of ready-to-eat vegetables in the Middle East. Food Control 62: 125-653.

8. Addis M, Sisay D (2015) A Review on Major Food Borne Bacterial Illnesses. Journal of Tropical diseases and Human Health 3:176.

9. Buck JW, Walcott RR, Beuchat LR (2003) Recent trends in microbiological safety of fruits and vegetables. Plant Health Progress doi:10.1094/PHP2003-0121-01-RV.

10. Heaton JC and Jones K (2008) Microbial contamination of fruit and vegetables and the behaviour of enteropathogens in the phyllosphere: A Review. Journal of Applied Microbiology 104: 613-626.

11. Tango CN, Wei S, Khan I, Hussain MS, Kounkeu PN, et al. (2018) Microbiological quality and safety of fresh fruits and vegetables at retail levels in korea. J Food Sci doi: 10.1111/1750-3841.13992.

12. Mritunjay SK, Kumar V (2015) Fresh farm produce as a source of pathogens: A Review. Research Journal of Environmental Toxicology 9(2): $59-70$

13. Campos J, Mourão J, Pestana N, Peixe L, Novais C, et al. (2013) Microbiological quality of ready-to-eat salads: an underestimated vehicle of bacteria and clinically relevant antibiotic resistance genes. International Journal of Food Microbiology 166(3): 464-470.

14. Pothakos V, Snauwaert C, De Vos P, Huys G, Devlieghere F (2014) Monitoring psychrotrophic lactic acid bacteria contamination in a readyto-eat vegetable salad production environment. Int J Food Microbiol 185: 7-16. 


\section{Your subsequent submission with Crimson Publishers} will attain the below benefits

- High-level peer review and editorial services

- Freely accessible online immediately upon publication

- Authors retain the copyright to their work

- Licensing it under a Creative Commons license

- Visibility through different online platforms

- Global attainment for your research

- Article availability in different formats (Pdf, E-pub, Full Text)

- Endless customer service

- Reasonable Membership services

- Reprints availability upon request

- One step article tracking system 